\title{
Antenatal Indomethacin Use Altering the Initial Presentation of Type 4A Bartter Syndrome
}

\author{
Priyanka Gupta $^{1} \cdot$ Rajendra Prasad Anne $^{1}$ (D) - Sai Kiran Deshabhotla ${ }^{1} \cdot$ Gayatri Nerakh $^{2}$
}

Received: 1 March 2021 / Accepted: 29 April 2021 / Published online: 7 June 2021

(C) Dr. K C Chaudhuri Foundation 2021

To the Editor: A 30-wk-3-d appropriate-for-gestational-age male neonate was born to a third degree consanguineous couple, with birth weight of $1.26 \mathrm{~kg}$. The mother was a $27-\mathrm{y}$-old primigravida, with polyhydramnios detected at 25 -wk gestation. Fetal growth was normal, with bilateral urinary tract dilatation and normal urinary bladder. Indomethacin was started and continued till delivery. Mother received antenatal steroids and $\mathrm{MgSO}_{4}$ for anticipated preterm delivery. She had premature rupture of membranes and preterm vaginal delivery. In NICU, the neonate had excess weight loss (10\% birth weight) by $24 \mathrm{~h}$-of-life. The fluid intake and urine output were appropriate; serum sodium - $124 \mathrm{mEq} / \mathrm{L}$, creatinine $-1.8 \mathrm{mg} / \mathrm{dL}$, urea $-130 \mathrm{mg} / \mathrm{dL}$, and high anion gap metabolic acidosis (HAGMA) were noted. In addition, we noted low serum chloride; normal potassium, calcium, blood pressures, cortisol, 17hydroxy progesterone, and sepsis markers; increased urine osmolarity and $\mathrm{FeNa}$, hypercalciuria; and abnormal renal sonogram (bilateral renal parenchymal changes with mild pelviectasis). As the maternal uncle had congenital deafness, possibility of type 4A Bartter syndrome (BS) was considered and clinical exome sequencing was conducted. Serum creatinine and metabolic acidosis normalized, but there was newonset hypokalemia. With appropriate fluid and electrolyte supplementation, the neonate started gaining weight.

Rajendra Prasad Anne rajendra.omc@gmail.com

1 Department of Neonatology, NICU, Unit 2, Fernandez Foundation, Opposite Old MLA Quarters, Hyderguda,

Hyderabad, Telangana 500029, India

2 Department of Medical Genetics, Fernandez Foundation, Hyderabad, Telangana, India
Clinical exome sequencing revealed homozygous missense variation in exon 1 of the $B S N D$ gene (chr1:g.54999214G > A; Depth:362x), confirming type 4A BS with sensorineural deafness $[1,2]$. Parents were counseled regarding the prognosis, and the need for parental and prenatal testing. The baby was discharged on day 33 at a weight of $1.42 \mathrm{~kg}$. At $3 \frac{1}{2}$ moof-life, the child was weighing $2.5 \mathrm{~kg}$. BERA confirmed profound hearing loss.

The neonate had several features of BS, but presence of HAGMA, normokalemia, and AKI posed diagnostic dilemma. Antenatal use of indomethacin can cause oliguria, AKI, edema, and hyperkalemia $[3,4]$. The index case highlights the altered presentation of BS because of transient renal adverse effects of antenatal indomethacin.

\section{Declarations}

Conflict of Interest None.

\section{References}

1. Birkenhäger R, Otto E, Schürmann MJ, et al. Mutation of BSND causes Bartter syndrome with sensorineural deafness and kidney failure. Nat Genet. 2001;29:310-4.

2. Estévez R, Boettger T, Stein V, et al. Barttin is a cl- channel betasubunit crucial for renal cl- reabsorption and inner ear $\mathrm{K}+$ secretion. Nature. 2001;414:558-61.

3. Bavoux F, Bavoux F. Toxicité foetale des anti-inflammatoires non stéroïdiens [fetal toxicity of non-steroidal anti-inflammatory agents]. Presse Med. 1992;21:1909-12.

4. Butler-O'Hara M, D'Angio CT. Risk of persistent renal insufficiency in premature infants following the prenatal use of indomethacin for suppression of preterm labor. J Perinatol. 2002;22:541-6.

Publisher's Note Springer Nature remains neutral with regard to jurisdictional claims in published maps and institutional affiliations. 